UDC 351.746.1

http://doi.org/10.21272/mmi.2018.4-28

JEL Classification: M67, F5, F52, P16

Wieslaw Jan Lewicki,

Ph.D., University of Technology Rzeszow, Poland

\title{
INNOVATIVE PROJECT MANAGEMENT: EU COMMON DEFENCE POLICY
}

Abstract. The article outlines the innovative project connected with the management of resources dedicated to the common defence policy in the EU. Describes the international community that undertook decisions towards the Common Safety and Defense Politics and therefore established European Union Force. The European Defence Community as an innovative management project. Current threats became the general determinants that were the basis for the decision of creating European Union Forces. The subject of enhancing the involvement of European Union countries in creating widely seen international safety community, as well as the limits that may be obstacles in forming and conducting activities concerning peace sustaining by European Union Force, is also present. Some of the foreseen aspects in cooperation with the United Nations Organization and North Atlantic Treaty Organization have been indicated. There is also an outline of political objectives that have to be fulfilled to make the idea of common armed forces. A brief story of the evolution of the idea of common European Forces has been shown as well as decisions that have been made at the consecutive meetings dedicated to their creation. There are also shown fundamental assumptions and requirements for the future European Union Forces with the special focus put to the EU task forces as the most effective tool in creating the Security Policy. Also presented the concepts of the establishment of permanent structural cooperation PESCO as the only prospect for the rationalization of defence expenditure in the European dimension. The organizational and legal requirements have been defined that the task forces need to meet and the abilities they need to achieve to join the combat duty in Quick Response Force of EU. According to the author, there are five key features that need to be met for battlegroups to achieve the adequate level of training and equipment to fulfil the wide spectrum of tasks concerning the crisis response as well as introducing peace in the source of conflicts not only in Europe.

Keywords: PESCO project, European defence community, European Union armed forces, European defence fund, ATHENA program, management, innovation project.

Introduction. The reassurance of security requires from international organizations the necessity of being able to react and intervene for stabilization and peace (Kitler, Marszalek,2014). Previous European activities connected with security were mainly conducted by political and economic means, such as diplomacy and activities of international organizations. Together with NATO, the EU also describes its security strategy as a common aim for global security. Modern security strategies point out a lot of different threats, such as: international terrorism, the weapon of mass destruction, local (Wrzosek, 2014) and regional conflicts, failed states, pandemics, international crimes or uncontrolled migrations. According to the present tendency in the outlook for security problems of European leaders, it's almost sure that in the near future the new international security system is going to be developed. The key element of this future European security system is the establishment of the European Union Army. Such an army would be able to react quickly, effectively detect all symptoms of threats and prevent European community from other dangers. Also, such an army would speak for the EU foreign policy.

The idea of the European Union Military Forces. The possibility of military integration is possible due to the Treaty of the European Union (The Maastricht Treaty, 1992). The $42^{\text {nd }}$ article in point $2^{\text {nd }}$ states that full military integration is possible in accordance with all member countries' agreement. Also, the $8^{\text {th }}$ point states that all countries which are eager to participate in such project are able to develop the stable, firm and integrative structure of the common safety policy. Some observers wonder if it's possible to establish the European Union Military Forces (Zieba, 2007) when there is a good and tested military organization - NATO. Moreover, almost all member countries are involved in NATO structures. Due to

Cite as: Lewicki, W. J. (2018). Innovative project management: EU common defence policy. Marketing and Management of Innovations, 4, 332-338. http://doi.org/10.21272/mmi.2018.4-28 
three elements, which are: the Brexit, the adoption of global strategy connected with foreign and defence policy of the EU and unwillingness of some member countries towards Donald Trump's (downloaded from the https://www.osw.waw.pl of the day 5 November 2018) foreign policy resulted in conclusion that European countries must diminish their dependency from the USA. Also, the EU notices the necessity of developing and enlarging its own security policy.

The first attempt of establishing strictly European army was in the beginnings of $50 \mathrm{~s}$ in the $20^{\text {th }}$ century. The project was presented by French Prime Minister Rene Pleven. His idea wasn't based on alliance (as NATO), but it posited the idea of The European Defense Community (Cichy, Szyjko, 2007), which contingents were supposed to be issued by all countries according to their possibilities and willingness. However, at the same time, all countries could possess their own military forces. Such solution was a response for growing military power of the USRR. Also, it was seen as a remedy for demilitarization in East Germany after the WWII. Pleven claimed that in case of any military conflict the formation would have been commanded by European NATO's command. The Netherlands also presented their own idea of such an army. This concept was based on international corpora but they were supposed to be commanded by their countries. Such solution was enthusiastically welcomed by the US president Dwight Eisenhower because it posited a significant backup to the American army in the face of growing military threats of the USRR. However, Great Britain was far less enthusiastic about the idea of establishing European military force, but due to American negotiations, the UK finally agreed to join the project. The treaty was signed in 1952 by France, Italy, Benelux countries and East Germany, however, it was never ratified by those countries. France was the first country which attempted to ratify the treaty but the French Parliament wasn't able to achieve the majority to ratify it. Moreover, Joseph Stalin's death and signed the armistice on the Korean Peninsula in 1953 significantly changed the global security situation and as a result, the idea of common military forces was abandoned.

Although the first attempts of establishing common military forces failed, the European community still worked on this idea. In 2004, the European Union Battle Groups (Iwanowski, 2014) were established. There came under the authority of the Council of European Union. They were supposed to be well trained and equipped military formations, which would have been used as a quick response group during unexpected military and humanitarian crisis. All conducted actions should be held at the UN and also should be held according to the United Nations Charter (Chapter 7). Such operations may be also commissioned by the UN (Kaczmarek, 2000). If the mission takes up to 120 days the EU Battle Groups are replaced by the UN soldiers. The range of the military operations has been settled up to $6000 \mathrm{~km}$ from Brussels (EU Military Rapid Response Concept, 2009). After analysis of Artemis(downloaded from the http://www.psz.pl of the day 5 November 2018) operation France, Germany and the UK claimed that the EU Battle Groups should be used in Africa. However, other member countries disagreed with this claim and were convinced that there shouldn't have been any geographical restrictions. Each battle group has $1500-2000$ soldiers. The decision of using and sending the group is taken by member countries' leaders or governments. The EU so far possessed 18 battle groups and they have never been used as a whole.

Establishing an organization of small battle groups and international units isn't a big logistic challenge, however, the establishment of the common military force may be considered as a problematic issue. The greater military integration has many arguments in favour, such as:

- sharing the costs and resources(downloaded from the https://www.globalfirepower.com of the day 10 November 2018);

- the cooperation of military industries- lower costs and better effectiveness;

- common defence policy can be improved;

- converging of military capabilities of all common countries.

The above-described solution will force all common countries to integrate all systems and military industries, e.g. now there are 17 different types of tanks in Europe, which may lead to logistic problems in 
case of military threats. The necessity of standardizing is obvious when it comes to technology integration of military and too low costs of new purchases. Such harmonization will result in developing leading European military products. Why is such cooperation essential? According to European Commission's data all member countries spend 227 billion Euro for defence, which equals to a half of American military budget (545 billion Euro), however, the EU countries manage to achieve only $15 \%$ of American results. One of the main cause of such disproportion may be the fact that in member countries there are 178 types of military ordnance while in American defence forces there are 30 (It shows how the unification of the EU military capability is necessary) of them. This situation is seen as an enormous challenge for managing European resources and must be treated as a priority.

European Defense Fund. In June 2017 the European Commission implemented the European Defense Fund, which is supposed to fund the development of technology and acquisition of new military abilities. On the 22nd June, the European leaders decided that all eager countries may build the core of the EU military defence. The EDF supports researches and advancement projects ( $90 \mathrm{mln}$ Euro in 2020 , $500 \mathrm{mln}$ Euro annually after 2020). However, the fund was mainly established to backup financially all aspects of military projects (2,5 billion euro in 2020 - 500 mln Euro comes from EU budget and 2 billion Euro is supposed to come from common countries' budgets). In 2021 the amount is raised to 5 billion Euro annually. The main aim of EDF is to enforce military independence from the most significant military partner - the USA. Some priorities have already been mentioned:

- unmanned aerial vehicles;

- midair refuelling;

- satellite communication and cyber abilities.

EDF is believed to contribute to enlargement of the common countries' military abilities based upon European arms capability. Additionally, the economic aspect of military politics in common countries is also very important. The EU countries still spend only 1,34\% GDP on average to military purposes.

Those initiatives are considered to be a great chance for increasing the common countries military abilities. Also, they may result in the increase in military investments or rationalization of defence financing. There is also the possibility of obtaining new markets for modern advanced military technologies. Taking all the above and future prospects into consideration The EU Council decided to establish a regular structural cooperation between member countries called PESCO (Oleksiewicz, Wozny, 2018). The treaty states, that only those countries which have already participated in the EU battle groups or have other significant military achievements may join the PESCO. In light of this, recent European Union initiatives relating to defence R\&D appear all the more important in helping states to spend smarter. The 25 out of 27 EU member states who joined the Permanent Structured Cooperation (PESCO) framework have agreed to 'ambitious and more binding common commitments'. This includes a 'successive medium-term increase in defence investment expenditure to $20 \%$ of total defence spending' and 'increasing the share of expenditure allocated to defence research and technology with a view to nearing the $2 \%$ of total defence spending' (Downloaded from https://www.iiss.org of the 10 November 2018). Such countries should be also ready to:

- increasing the budget for military purchases;

- building a common military unit;

- launching international military programs;

- enforcing of interoperability of already existing forces;

- enhancing the cooperation in logistics, training etc.

The PESCO is believed to enhance and reinforce the military cooperation within the EU. It's very probable that within PESCO only those really interested countries will cooperate. Such situation may result in better cooperation between countries (downloaded from http://jagiellonski24.pl of the 10 November 2018). Programs conducted within PESCO are first to be founded by the EDF. Also, PESCO is stated in 
the Treaty of the European Union in the $42^{\text {nd }}$ and $46^{\text {th }}$ article and in The Protocol of constant cooperation. Those documents describe all criteria which must be fulfilled by countries in order to join the treaty, such as the agreement to a given amount of investment spending included in the defence budgets, but not only:

- harmonization of modernization plans and development of capabilities;

- enhancement of availability, interoperability and ability of deployment;

- the obligation to refill all lacks in military capability;

- participation in the European Protection Agency programs.

The implementation of PESCO program is still discussed (Fiott, Missiroli, Tardy 2017). The main points are connected with cooperation in purchasing and using the same type of military equipment such as: European unmanned aerial vehicles, satellites, reconnaissance planes, coast guard ships, frigates and modern fighters. Next, the PESCO may serve as a platform for developing common land, air and naval forces in a consistent and standardized way (downloaded from https://ec.europa.eu of the 8 November 2018).

Although the implementation and further development of PESCO, as well as the establishment of EDF, are a significant step towards greater military independence of the EU community the establishment of the EU Military Forces is still considered to be rather a far perspective. Politicians are bound to eliminate all divisions and differences between common countries and lead to the development of the one defence policy. However, PESCO also may bring some threats to the unity of member countries within the EU structure. The enthusiasts of PESCO solution are mainly found among so-called "old" and most influential members, such as France, Germany and Italy (downloaded from http://www.rp.pl of the 7 November 2018). Even though the project is necessary for Europe due to many safety threats, such as: hybrid warfare, uncontrolled, massive migration and terrorism, many experts claim that it's almost impossible to implement it in the present political situation. It supposed to be possible in so-called many-speed Europe, where the core formed by most significant member countries will be ready for deeper integration (also in military issues) which may distance some countries like Poland (downloaded from http://www.pism.pl of the 5 November 2018).

Programming of the EU Military Forces. In June 2017 the member countries' leaders decided to establish a plan for structural military cooperation (PESCO). "It's a historic step" -said Donald Tusk the head of The European Council. PESCO was also supported by Germany (downloaded from https://www.nato.int of the 6 November 2018). Also, the French president Emmanuel Macrone is in favour of such a solution. In November 2018 during the celebration of the $100^{\text {th }}$ anniversary of the WWI ending Macrone said: "Europe should establish its own army in order to protect itself from The USA, Russia and China". The statement was noticed by the American president, who openly criticized such claims. Military cooperation is also welcomed by the less significant member countries such as Hungary. To Orban, the Brexit was the most powerful argument in favour of establishing the EU Military Forces. During summer course in Baile Tusnad in Romania Orban said: "NATO is a very important organization, which brought a sense of security to Hungary and other Middle Europe countries, however, the Brexit means that the EU military capabilities are bound to be diminished". According to Orban, the EU army should be established in order to protect European countries form potential threats.

However, not all common countries are so enthusiastic when it comes to the idea of common military forces. Traditionally, the most sceptical was the UK government. Against was also Polish politicians such as Grzegorz Schetyna. He said: "Warsaw is sure that NATO should be enforced as a priority. The idea of so-called "Euro army" according to us is detrimental (downloaded from https://wiadomosci.wp.pl of the 6 November 2018). The head of the Security Office, general Stanislaw Koziej pointed out that the idea of establishing the EU Military Forces is almost impossible to be implemented due to the lack of sources and weak European integration.

Despite enforcing military cooperation between member countries the so-called Euro-army is still far 
from actual implementation. When it takes into consideration all current threats, such an army seems to be a perfect solution, but it may be impossible to establish it in the present political situation in Europe.

The idea of European Defense Forces has already had many obstacles. (Sundelius, 2005) The most significant one is that common countries usually have different opinions when it comes to defence and economic policies. The governments of particular countries usually change after national elections. This results in different political visions and priorities. Such a situation may lead to conflicts and frictions between newly elected leaders. However, it seems that all common countries are now convinced that such formation as European Defense Forces should be established. The core of this future formation would be Eurocorps, which is a well-trained and extremely experienced unit. It may be a very important element of the EU Defense Forces in the future.

Eurocorps as a core of future common forces. Eurocorps or European Corps is an international military unit formed to rapidly respond to any crises. Also, it is involved in humanitarian, stabilization and peacekeeping missions.

It has been formed in 1992 as a military cooperation between France and Germany. After some time the formation begins to expand to other common countries and now there are 10 countries which are divided into two categories: the core countries which decide about the conducted tasks and they are: Germany (1992), France (1992), Belgium (1993), Spain (1994), Luxemburg (1996). The second group is called Observers which are: Poland (2002), Greece (2002), Turkey (2002), Italy (2009), Romania (2016).

Some countries such as Finland (2002-2006) Austria (2002-2011) and Canada (2002-2007) were members of Eurocorps, but now they don't participate in any tasks.

During the NATO summit in Warsaw in 2017, Eurocorps became an important unit within NATO structures. All decisions which are made within Eurocorps are balanced and divided between the Core Countries and the Observers. Yet, the observer countries are rather limited in final decision making.

The five core countries are entitled to approve all military operations in accordance with the decision of the Joint Committee. This body is composed of the chiefs of staffs, political directors of the Foreign Affairs Ministries. All Eurocorps operations must be held according to the UN instructions.

At the moment Eurocorps is able to conduct military operations which may involve up to 60.000 soldiers. The amount is created by units from core and observers countries. The fundamental land unit is Franco-German Brigade with 6000 soldiers. The brigade is usually firstly sent to the area of conflict. The core countries may, if it is necessary, generate additional military forces: France, Germany and Spain divisions, Belgium - brigades, Luxemburg- companies.

The first combat mission conducted by Eurocorps took place in 1998 in Bosnia and Herzegovina (SFOR). In 2000, Eurocorps took command in Kosovo's peacekeeping mission (KFOR). From August 2004 to February 2005 Eurocorps was responsible for ISAF stabilization mission in Afghanistan. Additionally, in 2002 Eurocorps was certified by NATO as High Readiness Force and NATO Response Force. In May 2006 Eurocorps reached a full operating capacity.

The next important initiative which is supposed to increase the effectiveness of financial aspects of military operations is the ATHENA project. This project is meant to finance all common costs during peacekeeping missions and all costs which are incurred by particular countries, such as accommodation, fuel, etc. The costs always covered:

- headquarters - establishment and all current expenses such as trips, IT systems, administration, public information, local personnel, deployment and accommodation;

- forces as a whole - facilities, medical care (area of activity), medical evacuation (MEDEVAC), identification and acquisition of information (satellite imageries);

- all shared costs towards NATO and other organizations (the UN).

The plan of the common multinational army is bound to encounter many different obstacles, such as financing issues. So, it is very important to forecast any future problems that may appear and gain as 
much experience as possible. ATHENA project seems to be a good platform to verify all decisions in practice.

Conclusions. The tremendous concern connected with the idea of EU Defense Force is that there is no clear political agreement when it comes to the use of such unit. The current political situation shows that there is a tendency to impose particular solutions with the use of majority voting without taking into consideration those countries which are against. If the military cooperation between member countries was integrated into such level that for instance, Poland would lose its legal and actual independence of using EU unit it would result in significant national safety risk. It is possible, that during safety risk situation for instance on the East of Poland, the decision-making process would be too long to effectively and quickly react to the particular threat. The only way to improve the situation is to intensify military and industry cooperation between member countries, such as establishing common command structures, multinational units and closer interoperability standards (O'Hanlon, 2017).

The European Defense Agency is claimed to be one of the most important elements in the process of formation of the new defence policy in Europe. The fund managed by the agency is intended to promote military independence of member countries. In 2020, its budget is planned to amount $590 \mathrm{mln}$ Euro, and in 20021-20027 this sum is supposed to be higher (5,5 billion Euro annually). The financial support can be provided only to those member countries which cooperate with each other within at least three entities. Moreover, only the most viable projects are going to be financed, those which are certain to bring the military benefits to the greatest number of EU countries.

The main aim of EDF is to standardize all procedures connected with obtaining the military hardware. Additionally, the Commission is going to support all small and medium-sized enterprises from the militaryindustrial sector. Finally, EDF is going to prioritize all military projects within PESCO, which is hoped to help in establishing the EU Defence Force in the future.

\section{References}

Cichy, A. Szyjko, C. (2007). Bezpieczenstwo miedzynarodowe w teorii i praktyce. AON, Warszawa.

Fiott, D. Missiroli, A. Tardy, T. (2017).Permanent Structured Cooperation: What's In a Name? EU Institute for Security Studies. Iwanowski, N. (2014). Teoria i praktyka wykorzystania grup bojowych Unii Europejskiej. AON, Warszawa.

Kaczmarek, J. (2000). NATO - Europa - Polska 2000. Atla2, Wrocław.

Kitler, W. Marszalek, M. (2014). Bezpieczenstwo narodowe i miedzynarodowe wobec wyzwan wspolczesnego swiata. AON, Warszawa.

O'Hanlon, M. (2017).Beyond NATO. A new security Architecture for Easter Europe, Washington.

EU Military Rapid Response Concept, Brussels, 23 January 2009, supersedes the previous UE Military Concept dated 16 September 2003

The Maastricht Treaty, Title V, Art. J.1., Maastricht 1992, s. XIV/PL $78-82$.

Oleksiewicz, I. Wozny, A. (2018). Bezpieczenstwo militarne i pozamilitarne w regionie UE-NATO. Rambler, Warszawa.

Sundelius, B. (2005). Disruptions - functional security for EU, Challiot Papers.

Wrzosek, M. (2012).Polska, Unia Europejska, NATO wobec wyzwan i zagrozen.AON, Warszawa.

Zieba,R. (2007). Wspólna Polityka Zagraniczna i Bezpieczenstwa Unii Europejskiej. Wydawnictwa Akademickie i Profesjonalne, Warszawa.

EUROCORPS, https://www.eurocorps.org (8 November 2018).

IIS https://www.iiss.org (10 November 2018)

Klub Jagiellonski, http://jagiellonski24.pl (10 November2018).

The EU Commission, https://ec.europa.eu ( 8 November 2018).

OSW - Centre of Eastern Studies, https://www.osw.waw.pl ( 5November 2018).

Polish Institute of Foreign Affairs, http://www.pism.pl (5 November 2018).

Przeglad NATO - NATO Review Magazine, https://www.nato.int (6 November 2018).

Rzeczpospolita, http://www.rp.pl (7 November 2018).

SIPRI https://www.sipri.org (10 November 2018)

Virtual Poland news, https://wiadomosci.wp.pl (6 November 2018). 
B. Я. Левицький, Ph.D., Ржешовский технологічний університет (Польща) Інноваційне управління проектами: спільна оборонна політика ЄС

У статті проаналізовано особливості реалізації інноваційного проекту щодо управління ресурсами при формуванні спільної оборонної політики Європейського Союзу (ЄС). Автор досліджує особливості міжнародного співтовариства у напрямі спільної політики безпеки та оборони, що в свою чергу формує Сили Європейського Союзу. У даному дослідженні створення єдиної оборонної системи розглядається як новий інноваційного проект. Автором визначено, що поточні загрози збереження стабільності в країнах ЄС стали підставою для прийняття рішення про формування Сил Європейського Союзу. у статті висвітлено особливості та проблеми посилення участі країн Європейського Союзу у створенні всеохоплюючоі спільної системи міжнародної безпеки, а також обмежень, які можуть стати перешкодами у формуванні та проведенні заходів, пов'язаних із підтриманням миру Силами Європейського Союзу. Проаналізовано проблеми та перспективи співпраці ЄС з Організацією Об'єднаних Націй та Організацією Північноатлантичного договору. За результатами дослідження було виокремлено низку політичних рішень, які необхідно виконати для формування спільних збройних сил ЄС. У статті представлено історію еволюції ідеї щодо спільних Сил Європейського Союзу, а також рішень, які були прийняті на послідовних зустрічах, присвячених їх створенню. Автором систематизовано основні припущення та вимоги до формування єдиних збройних сил Європейського Союзу з особливим акцентом на цільові групи ЄС як найбільш ефективний інструмент реалізації політики безпеки. У досліджені запропоновано концепцію створення постійного співробітництва PESCO як єдиноі перспективи для раціоналізації оборонних витрат у ЄС. Визначено організаційно-правові вимоги та кваліфбікаційні норми, які повинні мати претенденти до вступу у Сили Європейського Союзу. У роботі автор виокремлює п'ять ключових елементів, які необхідно виконати для бойових груп, щоб досягти відповідного рівня підготовки та оснащення для виконання широкого спектру завдань, що стосуються реагування на кризу, а також встановлення миру в джерелі конфліктів не лише в Європі.

Ключові слова: проект, PESCO, Європейська оборонна спільнота, Збройні сили, Європейський оборонний фонд, ATHENA, менеджмент, інноваційний проект.

Manuscript received: 18.10 .2018

(c) The author(s) 2018. This article is published with open access at Sumy State University. 